\title{
Making Simple Repairs: Clogged Drains ${ }^{1}$
}

Mary N. Harrison ${ }^{2}$

Clogged drains can create a problem. However, a few simple precautions will help you to keep the drains open and in good working condition.

- After washing your head, clean the hair out of the drain.

- Never pour grease or greasy fluids down a drain. Grease hardens and will clog a drain. Pour used grease into a can to cool before putting it into a plastic bag. Put the bag in the garbage. Clean the greasy pan with hot water and detergents.

- Keep the drain strainer in your kitchen sink to catch small bits of food. Clean the strainer after each use.

\section{Supplies Needed:}

- Simple suction plunger

\section{How To Fix a Clogged Sink}

- In a single bowl sink, plug the overflow opening with a washcloth or rag. In a double bowl sink, plug the other drain. Keep these plugs in place.
- Place the plunger over the mouth of the drain. Press plunger down smoothly. Then, jerk the plunger up sharply.

- Repeat 20-30 times.

- If this removes the clog, rinse the drain with hot soapy water.

- If this does not unplug the sink, repeat.

If the drain is still stopped-up, check to see if the trap has a cleanout plug. (The trap is the $\underline{\mathrm{U}}$ shaped part of the pipe under your sink.)

- If there is a cleanout plug, place a pan or bucket under the trap.

- Unscrew the cleanout plug with an adjustable wrench.

- Most clogs are in the trap. Use your finger, a pencil, or wire to clean the clog from the trap.

If this cleans the clog, replace the cleanout plug. Screw it together, then run hot, soapy water through the drain.

1. This document is FCS5234-05 one of a series of the Department of Family, Youth and Community Sciences, Florida Cooperative Extension Service, Institute of Food and Agriculture Sciences, University of Florida. Publication: May 2002. Revised: December 2005. Please visit the EDIS Web site at http://edis.ifas.ufl.edu.

2. Mary N. Harrison, professor, Department of Family, Youth and Community Sciences, Cooperative Extension Service, Institute of Food and Agricultural Sciences, University of Florida, Gainesville, 32611.

The Institute of Food and Agricultural Sciences (IFAS) is an Equal Opportunity Institution authorized to provide research, educational information and other services only to individuals and institutions that function with non-discrimination with respect to race, creed, color, religion, age, disability, sex, sexual orientation, marital status, national origin, political opinions or affiliations. U.S. Department of Agriculture, Cooperative Extension Service, University of Florida, IFAS, Florida A. \& M. University Cooperative Extension Program, and Boards of County Commissioners Cooperating. Larry Arrington, Dean 
- If this effort does not remove the clog or the trap does not have a clean out plug, notify your landlord or call a plumber.

\section{How to Fix a Clogged Bathtub Drain}

Supplies Needed:

- Screwdriver

- Plunger

\section{The basic bathtub}

- Cover the overflow drain with a wet washcloth or rag.

- Remove the stopper or closure from the bathtub drain.

- Fill the tub to a depth of about 2 inches.

- Place the plunger over the drain.

- Holding the cloth over the overflow drain, push the plunger down. Jerk it back up. Repeat this 20-30 times.

\section{Bathtubs with lever closures}

Bathtubs with lever closures:

- Some tubs have a lever on the overflow drain, which raises the cover of the bathtub drain.

- For these tubs, lift the drain cover out of the tub. Clean the extension of the cover.

- Unscrew the two screws holding the overflow cover. Place the two screws in a container away from the tub to avoid losing them.

- Remove the overflow cover. It has a rod and coil attached. Clean the coils attached to the cover. These coils collect hair, soap scum, and body oils.

- Run water through the drain. Use the plunger if needed.

- Put the coil and rod back in the overflow and refasten the cover with the screws.
- Put the bathtub drain cover back in the tub.

\section{Chemical Drain Cleaners}

\section{Chemical drain cleaner facts}

Chemical drain cleaners are:

- Highly advertised and widely used.

- Helpful only for sluggish drains.

- Toxic and should be stored and handled with extreme care.

- Bad for septic tanks.

- Caustic and could burn you or damage pipes or fixture finishes.

How to use a chemical drain cleaner

- Open windows and doors.

- Wear rubber gloves to prevent burning your hands.

- Read labels carefully and follow the instructions!

- DO NOT mix chemicals-if you use one brand that did not work, DO NOT use another brand or type on top of it-it may produce DEADLY fumes!

- DO NOT look or hold your head over the drain.

- DO NOT use plunger. 